Journal of Universal Computer Science, vol. 26, no. 2 (2020), 200-219

submitted: 19/3/2019, accepted: 10/2/2020, appeared: 28/2/2020 CC BY-ND 4.0

\title{
Co-Creation of e-Learning Content: The Case Study of a MOOC on Health and Cyber-Bullying
}

\author{
Fernando Ferri \\ (Istituto di Ricerche sulla Popolazione e le Politiche Sociali \\ Consiglio Nazionale delle Ricerche, Rome, Italy \\ fernando.ferri@irpps.cnr.it) \\ Alessia D'Andrea \\ (Istituto di Ricerche sulla Popolazione e le Politiche Sociali \\ Consiglio Nazionale delle Ricerche, Rome, Italy \\ alessia.dandrea@irpps.cnr.it) \\ Arianna D'Ulizia* \\ (Istituto di Ricerche sulla Popolazione e le Politiche Sociali \\ Consiglio Nazionale delle Ricerche, Rome, Italy \\ *Corresponding author \\ arianna.dulizia@irpps.cnr.it) \\ Patrizia Grifoni \\ (Istituto di Ricerche sulla Popolazione e le Politiche Sociali \\ Consiglio Nazionale delle Ricerche, Rome, Italy \\ patrizia.grifoni@irpps.cnr.it)
}

\begin{abstract}
The use of a co-creation process within e-learning practices enables learners to live positive experiences as they are more actively involved in the learning process. Starting from this consideration, the paper aims to demonstrate that using a co-creation approach to design a Massive Open Online Course allows amplification of the learning experience as well as the children's knowledge and awareness of digital health literacy issues, particularly of cyberbullying. To this end, a case study that involves teachers and students from a primary school in Rome has been implemented. To engage students, two participative methodologies (open space technology and storytelling) are used. The results of the case study show a positive impact of the co-creation strategy on both the students' engagement in co-producing the learning content and their awareness and knowledge of the cyber-bullying phenomenon and digital health literacy issues.
\end{abstract}

Keywords: Massive Open Online Course, digital learning, co-creation, cyber-bullying Categories: L.1.2, L.3.0, L.3.4, L.6.2

\section{$1 \quad$ Introduction}

The increasing proliferation of information and communication technologies in the lives of young people has favoured the emergence of a new form of bullying, called cyber-bullying. This phenomenon involves hurting someone else using internetconnected mobile phones or personal computers through emails, websites, chats, instant messaging, etc. A survey conducted by Garaigordobil and Martínez-Valderrey 
[Garaigordobil, 2018], which analysed the results of 309 epidemiological studies examining cyber-bullying behaviours among students, reported that the mean percentage of victims of cyber-bullying ranges from 1 per cent to 10 per cent, with a peak of 60 per cent of students who suffer cyber-bullying behaviour in some studies. These numbers testify that cyber-bullying is a frequent phenomenon in modern schools and it has become an international public health concern among adolescents [Kowalski, 2012]. Consequently, there is a growing need to face this problem in order to counter and reduce cyber-bullying actions in school.

In the opinion of experts, information and communication technologies may become effective tools to promote anti-bullying messages, especially if they speak to young people in their language. Several researchers [Nocentini, 2015; Topcu-Uzer, 2018] have shown that school-based interventions using technology as a learning tool may have positive effects on increasing student awareness of digital health literacy and cyber-bullying. As defined by Norman and Skinner [Norman, 2006], digital health literacy refers to the ability to seek, find, understand, and appraise health information from electronic sources and apply the knowledge gained to addressing or solving a health problem. According to Küter-Luks, Heuvelman and Peters [Küter-Luks, 2011], indeed, to educate to digital health literacy during preadolescence (ages 9-12 years) is fundamental because the adolescents are most vulnerable to negative effects of media, such as increased negative emotions and depression, negative body image, a more positive view towards substance use, a sexualised vision of adolescence, and more aggressive behaviour. Further research studies [Ashktorab, 2016; Garaigordobil, 2018] have engaged students in the process of design of technological learning tools against cyber-bullying in order to strengthen these effects.

The study presented in this paper aligns with this perspective. Specifically, it integrates two technological solutions (i) video storytelling and (ii) the Massive Open Online Course (MOOC) design within a co-creation strategy with the aim of amplifying both the learning experience and the children's knowledge and awareness of digital health literacy issues, and particularly of cyber-bullying. To engage students, two participative methodologies (open space technology and storytelling) are used. Teachers and students aged 9 to 10 from a primary school in Rome are engaged to cocreate the MOOC. The defined co-creation strategy applies different techniques integrating face-to-face participatory meetings and online activities for the design, development and fruition of the MOOC. The obtained findings consolidate the idea that using technological solutions is an effective way of amplifying the learning experience as well as the children's knowledge and awareness of digital health literacy issues, and particularly of cyber-bullying.

The main contribution of the proposed methodology, compared to the existing school-based interventions using technological learning tools proposed in the literature, relies on the fact that it extends the use of technology to the phase of designing the elearning tools with the students by adopting a co-creation approach. Co-creation is a participatory process in which all participants are brought together in order to jointly produce with a mutually valued output. This methodology is beneficial to involve young people in the establishment of a broad discussion leading to the emergence of sustainable solutions and opportunities to prevent unhealthy habits and behaviours.

The study is conducted within the European research project 'IC-Health: Improving the digital health literacy of European citizens' (https://ichealth.eu/), funded under the Horizon 2020 programme (Grant no. 727474), that aims at involving different 
population cohorts in the co-creation of MOOCs for the improvement of digital health literacy in Europe.

The paper is structured as follows. After introducing the literature review related to the co-creation process in the e-learning field, MOOC use for young education, and technology-enhanced solutions for mitigating cyber-bullying (Section 2), the applied co-creation strategy for the MOOC design and development is described in Section 3. Section 4 illustrates the case study on the design and development of a MOOC on health and cyber-bullying. Section 5 discusses the case study results. Finally, Section 6 concludes the paper.

\section{Literature Review}

In this section, an overview of the co-creation process, some experiences of use of MOOCs for young education, and several existing technology-enhanced solutions for mitigating cyber-bullying at school are given.

\subsection{The Co-Creation Process and the e-Learning}

The co-creation process allows the identification of ideas and/or solutions that are perceived as novel, unique, useful and relevant for the design, development and innovation of a service and/or product [Ferri, 2013; D’Andrea, 2015]. Frow et al. [Frow, 2011] define co-creation as "an interactive process involving at least two willing resources integrating actors who are engaged in a specific form(s) of mutually beneficial collaboration, resulting in value creation for those actors" (p. 1). Based on this definition, in the co-creation process all members are equally important. Through interaction, each member gets an opportunity to influence the value-creating process. Co-creation is relevant for producing the effective engagement of teachers and students in learning activities.

Learners and teachers' engagement is the key idea of engagement theory, a framework for technology-based teaching and learning first developed by Kearsley and Shneiderman [Kearsley, 1998]. Engagement theory aims to establish successful cooperation teams in non-traditional teaching environments stimulated by the widespread diffusion of mobile devices and social media that amplify the collaborative dynamics among learners [D’Andrea, 2009;Ferri, 2018; Caschera, 2019]. Engagement theory relies on three basic principles: relate, create and donate. 'Relate' emphasizes that learners communicate and cooperate to accomplish a task. 'Create' regards learning as a creative, purposeful activity, and 'donate' encourages learners to contribute to the improvement of community knowledge [Huang, 2010]. Following these principles, cocreation can be understood as a way to activate and manage creative processes among the learners that are at the centre of the e-learning process as active sources of knowledge, motivation and ideas. Fostering inter-creative activities facilitates cocreation and increases learners' engagement [Osuna-Acedo, 2017b]. Actually, cocreation is an ever-more prevalent mechanism of e-learning that affords new, innovative and positive dynamics in the engagement and participation of learners.

The co-creation process strongly influences e-learning. With the increasing use of e-learning technologies, the role of students is shifting from passive receivers of knowledge transmitted through teaching to active contributors and co-creators of 
education outcomes such as knowledge, personality traits, skills, etc. [Díaz-Méndez, 2012]. Co-creation allows enhancement of the students' engagement, motivation, metacognitive awareness and sense of identity [Caschera, 2011; Nygaard, 2013; CookSather, 2014; Ferri, 2014]. According to Bovill [Bovill 2014], the idea of students as active actors has recently gained increasing favour in e-learning practices. Academic staff are also intrigued by the possibility of adopting co-creation approaches in their elearning practices; however, they struggle with the new challenges as they move beyond traditional roles [Allin, 2014].

In this paper, the co-creation approach has been followed to engage learners in the design and development of e-learning content by sharing experience, knowledge and opinions.

\subsection{Massive Open Online Courses for Young Education}

Among the e-learning approaches, MOOCs have received a lot of interest in educational and technological research. They are, by definition, free online courses offered to great masses through virtual learning environments. Therefore, they act as potential 'change agents' in teaching and learning activities [Liyanagunawardena, 2013]. The spread of MOOCs needs attention from all people engaged in teaching and learning activities that have the chance to improve their competencies and skills [Agrusti, 2017]. Several types of MOOC exist in the literature, some of which are:

(i) cMOOCs, or connectivist MOOCs, which are designed to emphasize collaboration as a form of active learning; they give more attention to connecting learners than presenting content.

(ii) xMOOCs, which follow traditional course structures, make use of established teaching approaches and materials, and are less interactive.

(iii) sMOOCs, or social MOOCs, which incorporate a greater degree of social interaction and participation than cMOOCs and XMOOCs [Osuna-Acedo, 2017a].

To fully exploit the potential of the MOOCs, a critical activity is represented by the design and development processes. MOOC design has been identified as a central theme of future MOOC research [Gašević, 2014]. Several studies provided in the literature have followed a team-based approach to designing and developing a MOOC [Puzziferro, 2008; Bartoletti, 2016; White, 2016]. In particular, it is important to involve teachers and learners in the MOOC design and development process to provide effective learning content. Putting the learner at the centre of the process (learnercentred approach) allows the development of targeted and self-traced competencies and improved engagement in the learning activities [Guàrdia, 2013].

In this paper, the principles of engagement theory have been followed to engage learners in the co-creation of MOOC structure and content. The developed MOOC can be categorized as an $\mathrm{SMOOC}$ since it is characterized by interactions and participation, and integrates several real-life experiences of participants. 


\subsection{Technology-Enhanced Solutions for Mitigating Cyber-Bullying at School}

To combat cyber-bullying, several school-based interventions have been proposed in the literature, which can be classified into three types: i) law and policy; ii) curriculum and campaigns; and iii) technological responses. This sub-section investigates some existing interventions belonging to the third category, since it is the most relevant for the article.

The existing interventions apply different technological approaches, ranging from video storytelling to virtual games and adaptive user interfaces. Bowler et al. [Bowler, 2014] proposed a user-generated conceptual framework for understanding and guiding the design of social media through the use of video storytelling that allows high school students to map out a cyber-bullying story and overlay it with a set of design recommendations. Dinakar et al. [Dinakar, 2012] looked at preventing cyber-bullying by using a reflective user interface design, an approach that encourages positive digital behavioural norms through notifications, action delays, displaying hidden consequences, system-suggested flagging, interactive education, and the visualization of aggregated data. Garaigordobil et al. [Garaigordobil, 2018] proposed a videogame called Cooperative Cybereduca 2.0, which aims to prevent and reduce cyber-bullying during adolescence by promoting communication, increasing prosocial behaviour and enhancing group cohesion. The videogame is organized as a cybernetic trivial pursuit game consisting of questions and answers around the topic of cyber-bullying.

In this paper, video storytelling has been used since it is the most useful technological solution for encouraging students to talk about their cyber-bullying experiences.

\section{A Co-Creation Strategy for the MOOC Design and Development}

The solution proposed in this paper integrates the video storytelling and the MOOC design within a co-creation strategy to amplify the learning experience as well as the children's knowledge and awareness of digital health literacy issues, and particularly of cyber-bullying. To engage students, two participative methodologies (open space technology and storytelling) are used.

The co-creation strategy for the MOOC design and development is based on meetings that happen both offline, through face-to-face meetings, and online, through online communities working on a dedicated web-based platform. The use of online communities and educational social networks increases the possibilities for interaction and sharing within learning groups [Caschera, 2010; Caschera, 2012]. The reason for organizing face-to-face meetings is to build stronger and meaningful student relationships. Face-to-face meetings are dynamic; they allow students to be easily broken up into smaller groups to discuss and collect ideas.

During the meetings, different methodologies are used, such as open space technology, questionnaires, storytelling and drawing. The open space technology stimulates students' ability to listen and truly consider the different perspectives, allowing insight to recognize and accept the solution that best serves the whole. Moreover, it stimulates the ability to work in a group towards a common goal. Use of the questionnaire allows the collection of large amounts of information in a short time 
and in a relatively cost-effective way, while storytelling is useful to enhance students' memory and awareness. Once students have told a story, teachers can ask them to repeat the same after a few days. This is a fun way to increase their memory and encourage concentration. To stimulate students' creativity, the drawing methodology has been used. Drawing gives students a chance to be themselves since there are no rules and regulations to be followed; they are free to put their imagination on paper without words.

The strategy consists of seven different steps, as shown in Figure 1.

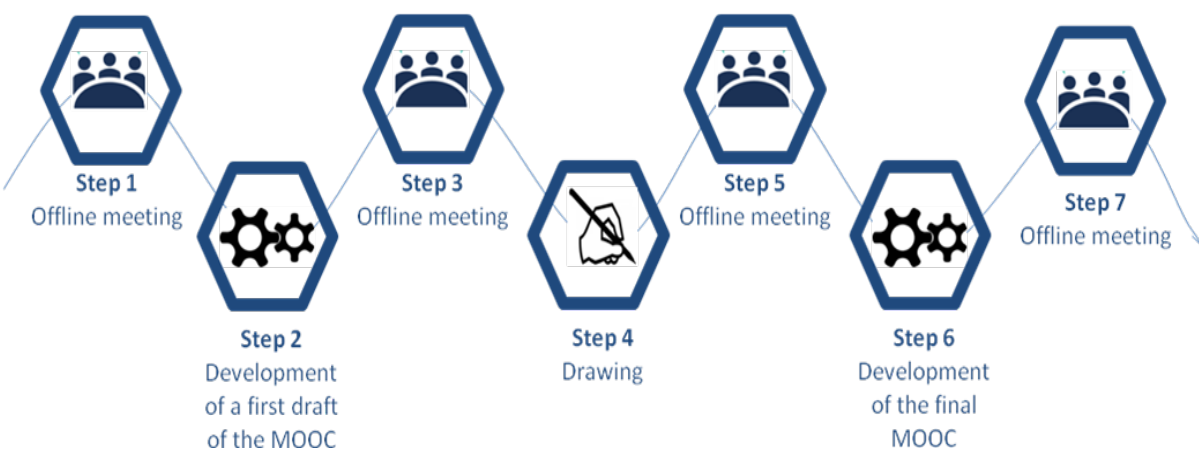

Figure 1: The steps of the co-creation process for the MOOC design

The first step consists of an offline meeting with learners and teachers of the MOOC (co-creators) involved according to the topic of the MOOC. During the meeting, the objectives of the MOOC are illustrated. Using a storytelling methodology, each learner tells his/her own experience on the specific topic. A questionnaire is administered to the co-creators to evaluate their starting knowledge about the MOOC topic and to compare it with the final knowledge acquired after the MOOC fruition.

In the second step, the storytelling and the answers to the questionnaire are analysed to extract information on the experiences, difficulties, needs and knowledge of the co-creators on the MOOC topic. The extracted information is used to define the structure of the MOOC and the first draft of some contents.

During the third step, a second offline meeting with the co-creators is organized. The first draft of the MOOC is visualized by the co-creators, who make comments and offer suggestions to improve the MOOC during an open space section.

In the fourth step, learners are involved to produce a drawing representing the MOOC topic.

A third offline meeting with the co-creators is organized during the fifth step of the co-creation process. By using a video storytelling methodology, each learner tells a story on the MOOC topic by describing his/her drawing. Moreover, the co-creators read the MOOC contents prepared during the second step of the co-creation strategy. A team of experts records all the stories and voices of co-creators during the meeting for editing the videos. 
In the sixth step, the final version of the MOOC is developed by integrating the drawings, stories and voices of the learners, as well as the comments and suggestions that emerged during the third step.

Finally, the last step consists of an offline meeting to test and evaluate the MOOC. The facilitation and co-creation technique used during the meeting is open space technology (http://www.chriscorrigan.com/openspace/whatisos.html) integrated with the fruition of the different lessons of the final version of the MOOC available on the IC-Health platform (http://ichealthplatform.eu/). After the fruition of the MOOC, an online evaluation questionnaire is administered to the co-creators to assess the quality of both the co-creation activities and the resultant MOOC. The online evaluation questionnaire contains questions on the acquired skills and the quality of the MOOC structure.

\section{The MOOC on Health and Cyber-Bullying: A Case Study}

The co-creation strategy defined in the previous section has been used to design and develop the MOOC on health and cyber-bullying in the framework of the activities of the IC-Health H2020 project (https://ichealth.eu/). The project aims to provide support for the improvement of digital health literacy in Europe. Citizens' digital health literacy is an essential element for successful e-health deployment. However, citizens do not always have the necessary skills to find, understand and appraise online health information and apply their knowledge to make health decisions [D'Andrea, 2010; Guzzo, 2014]. Digitally health literate citizens are empowered to play a more active role in their health self-management, resulting in improved prevention, adherence to a healthier lifestyle and better health outcomes. In particular, the IC-Health project produces MOOCs on different topics.

For the MOOC creation, the case study methodology has been used. The case study methodology is based on "an in-depth investigation of a single individual or groups and it provides a systematic way of looking at events, analysing information, collecting data and reporting the results needed" [Feagin, 1991] (p. 28). Abercrombie, Hill, and Turner [Abercrombie, 1984] define a case study as "the detailed examination of a single example of a class of phenomena... a case study cannot provide reliable information about the broader class, but it may be useful in the preliminary stages of an investigation since it provides hypotheses, which may be tested systematically with a larger number of cases" (p. 34). This methodology was introduced into social science in 1879 by Frederic Le Play [Le Play, 1879] as a handmaiden to statistics in his studies of family budgets. It was further developed by two sociologists, Barney Glaser and Anselm Strauss, who presented their research method 'grounded theory' in 1967. According to Vissak [Vissak, 2010], "the case study methodology is a very useful method as it allows expanding and generalizing theories by combining the existing theoretical knowledge with new empirical insights" (p. 371).

The case study methodology used in this paper follows the approach provided by many researchers [Miles, 1984; Eisenhardt, 1989; Yin, 1994; Stake, 1995; Crabtree, 1999; Devers, 1999; Ryan, 2000], which consists of the following steps: (i) defining the research question; (ii) determining techniques for data gathering; (iii) preparing to collect the data; (iv) collecting data in the field; (v) evaluating and analysing the data; 
and (vi) preparing a report. In the remainder of this section, a description of how each of these steps has been implemented is provided.

\subsection{Defining the Research Question}

Addressing cyber-bullying issues entails a solid understanding of each of its components. First of all, the interest of the study was the students' opinions on cyberbullying in general. Prevention and intervention strategies to counter and reduce cyberbullying actions were also considered. Finally, particular attention was given to technological tools for amplifying the learning experience as well as the children's knowledge and awareness of digital health literacy issues and particularly of cyberbullying. Specifically, the following research questions guided this exploration:

- How can cyber-bullying be prevented in school?

- What is students' knowledge and awareness of digital health literacy and cyber-bullying?

- How do technology-enhanced interventions improve students' knowledge and awareness of digital health literacy and cyber-bullying?

The hypothesis behind the study is the following: "the use of a co-creation process in the design and development of a MOOC amplifies the learning experience as well as the children's knowledge and awareness of digital health literacy issues, and particularly of cyber-bullying".

\subsection{Determining Techniques for Data Gathering}

Techniques for data gathering used during the meetings are open space technology, questionnaires, storytelling and drawing. The open space technology has been used to help students become more effective in discussing the cyber-bullying issues by developing their skills as lifelong learners and collaborative problem solvers. It creates the conditions to realize the maximum potential of the students. The questionnaires allow studying of the social environment of a school and further understanding of the students' knowledge and experiences on cyber-bullying in the simplest way. Finally, storytelling and drawing represent powerful methods to encourage students to talk about cyber-bullying experiences.

\subsection{Preparing to Collect the Data}

All schools have a legal responsibility to prevent discrimination and victimization within the school and tackle cyber-bullying. This drove the Pestalozzi school to participate in the study. In particular, two teachers and 30 students of the Pestalozzi school were involved. The role of the teachers is to support students during the cocreation strategy; moreover, they have an active advisory role during the MOOC implementation.

Since the students who participated in the study were minors, informed consent from the parents was required. Note that the Pestalozzi school, at the beginning of each year, asks the children's families for informed consent for the students' involvement in projects in which the school participates, also asking them for permission to take pictures of children during these activities. 
As required by the co-creation strategy defined in the previous section, three offline and one offline/online meeting were organized. In the following sections, the different outputs from the different meetings are discussed.

\subsection{Collecting Data in the Field}

During the first meeting, the objectives of the IC-Health project were illustrated. Using a storytelling methodology, each child told his/her own experience of both use of the internet to search health information and cyber-bullying (lived and observed) events. A first questionnaire was administered to 30 children to understand their experiences, difficulties and needs on the topic to define the MOOC content. The questions and the results of this first questionnaire are shown in Table 1.

Analysis of the results of the first questionnaire underlined children's low experience of both digital health literacy and cyber-bullying. Indeed, only 16.6 per cent of the children had searched the internet to find useful information on cyber-bullying. Moreover, 60 per cent had never experienced receiving offensive posts about other people; children that had cyber-bullying experiences $(37 \%)$ reacted by ignoring them $(54.4 \%)$ or telling an adult/teacher $(45.5 \%)$.

The low digital health literacy experiences of children were also underlined by their difficulties in understanding the reliability of both information found on the internet $(37 \%)$ and sources of information $(50 \%)$.

Respect for privacy is a need underlined by 67 per cent of children. The majority of them $(60 \%)$ ask for consent to post or share personal photos, videos or messages. A high percentage $(60 \%)$ also consider it very relevant to gain the permission of their friends before sharing content, photos or videos about them on the internet, while 33 per cent never ask permission.

During the second offline meeting, the first draft of the MOOC was looked at by children and teachers, who expressed comments and suggestions to improve the MOOC during an open space section. Based on the received comments, the first draft of the MOOC was considered to be very detailed and explained in the best way possible, making it easy for anyone to understand the cyber-bullying issue. It covered all the basic knowledge and even helped with prevention actions. Received suggestions to improve the MOOC were on content considered as repetitive; they suggested adding more concise content with the use of animated characters.

During a school lesson, teachers involved learners in making a drawing representing how they imagine a cyber-bully. Some examples of the drawings made by students are illustrated in Figure 2. 


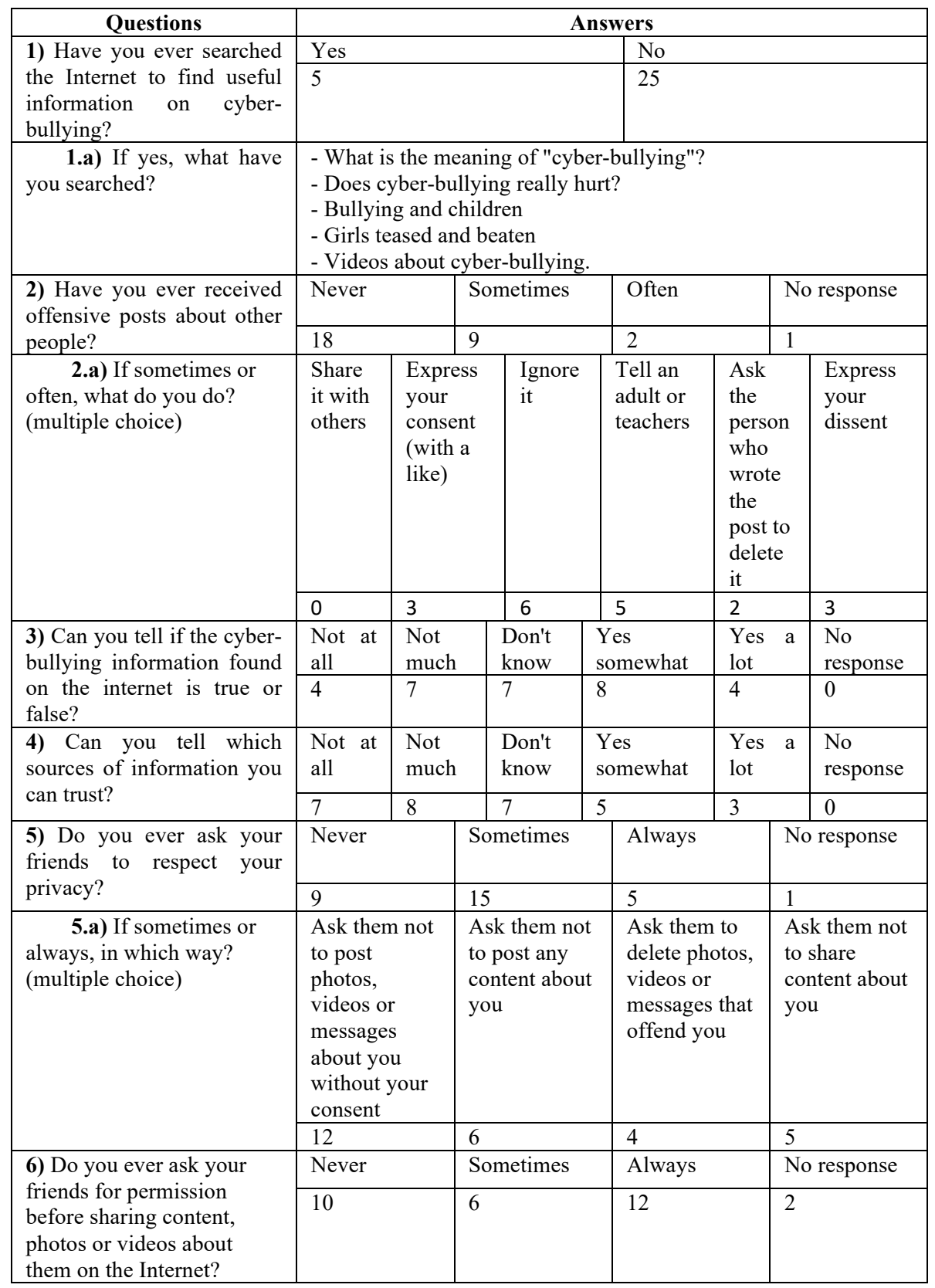

Table 1: First questionnaire and students' answers 


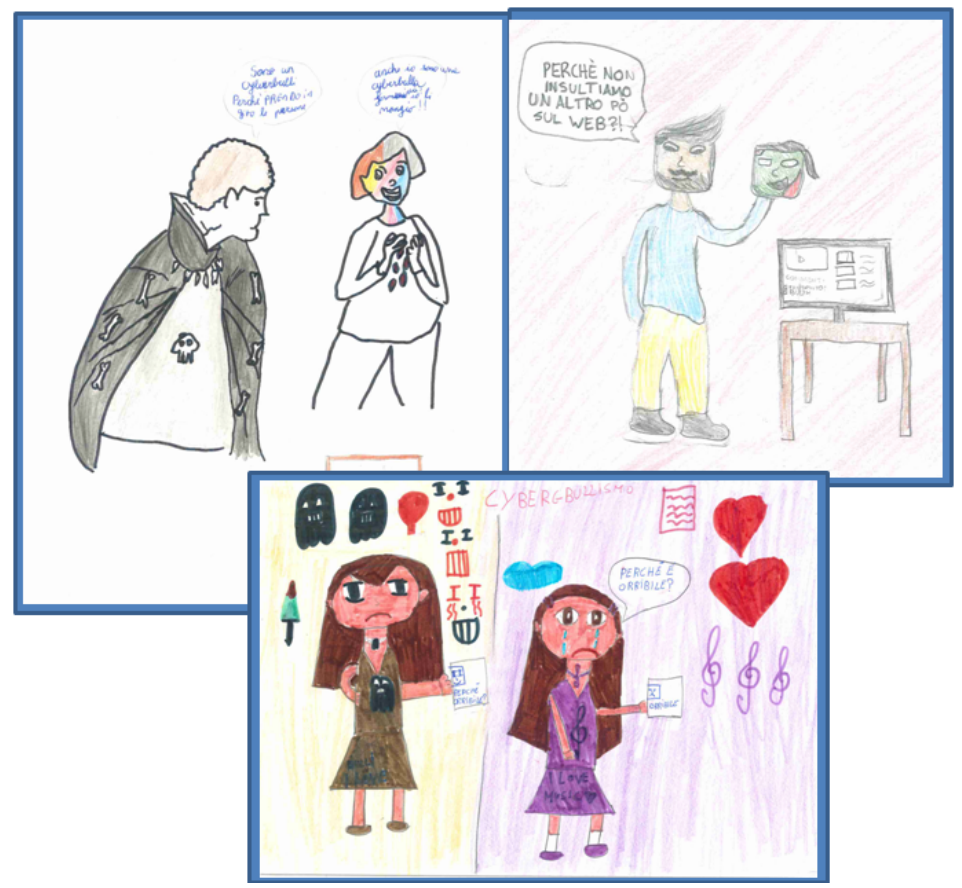

Figure 2: Some of the drawings made by students involved in the co-creation of the MOOC on health and cyber-bullying

In the third offline meeting, children were involved in a storytelling section; each child told a story on cyber-bullying by describing his/her drawing. Moreover, children read the MOOC contents prepared during the second step of the co-creation process. A team of experts recorded all the stories and voices of children during the meeting. An example of a video resulting from these activities is available on the YouTube platform. ${ }^{1}$

Following the comments and suggestions received during the previously described steps and using the collected material, the final version of the MOOC was developed on the IC-Health platform. Figure 3 shows a screenshot of the developed MOOC.

\footnotetext{
1 An example of the storytelling videos can be found at the following link: https://www.youtube.com/watch?v=e96Vjhzfln4\&feature=youtu.be
} 

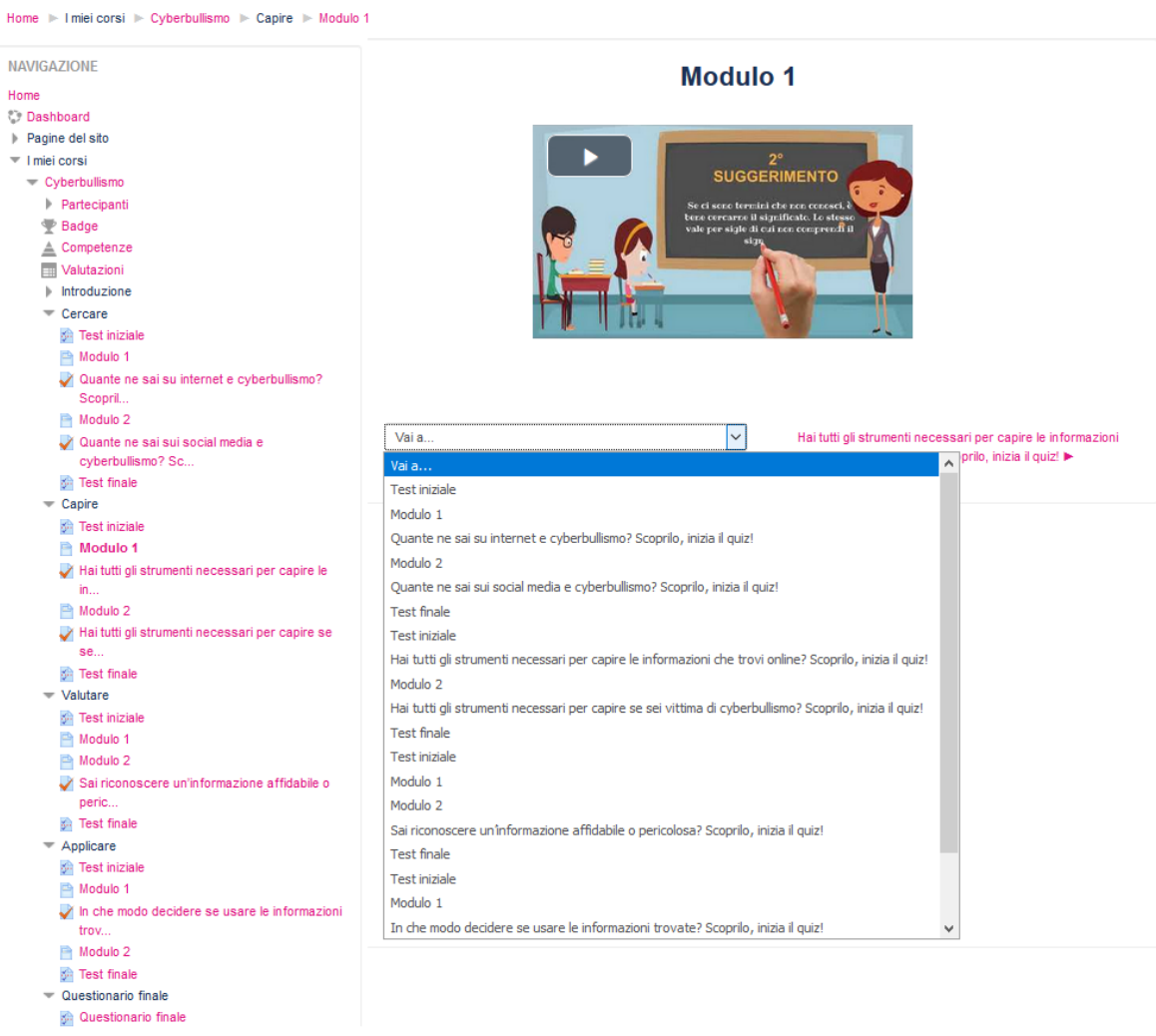

Figure 3: The final version of the MOOC on health and cyber-bullying

The last organized meeting consisted of online and offline activities. A room with 30 PCs was arranged within our research institute in Rome. First of all, children were asked to register on the IC-Health platform and to subscribe to the online community on health and cyber-bullying. Through this online community, children accessed and interacted with the MOOC contents. Before seeing each lesson of the MOOC, the children were asked to answer a pre-self-assessment question to evaluate their starting knowledge about the topic. Children followed the five lessons of the MOOC (illustrated in Table 2) and completed the tests and quizzes contained in each lesson. Videos of the lessons are available on the YouTube platform. ${ }^{2}$ At the end of each lesson, children were asked a post-self-assessment question to compare their final knowledge with their starting knowledge (see Table 3).

2 An example of a lesson video can be found at the following link: https://www.youtube.com/watch?v=ggr8Ytbp $7 t 4 \&$ feature=youtu.be 


\begin{tabular}{|l|l|l|}
\hline Lesson & Aims & Type of Content \\
\hline $\begin{array}{l}\text { Lesson 1 } \\
\text { INTRODUCTION }\end{array}$ & $\begin{array}{l}\text { The lesson introduces the MOOC on } \\
\text { health and cyber-bullying }\end{array}$ & Text-based, videos \\
\hline $\begin{array}{l}\text { Lesson 2 } \\
\text { FIND }\end{array}$ & $\begin{array}{l}\text { The lesson provides some suggestions } \\
\text { on how to search for information, } \\
\text { groups, videos, photos, etc. and } \\
\text { exchange them on social media to } \\
\text { prevent cyber-bullying }\end{array}$ & $\begin{array}{l}\text { Text-based, videos, } \\
\text { interactive quizzes }\end{array}$ \\
\hline $\begin{array}{l}\text { Lesson 3 } \\
\text { UNDERSTAND }\end{array}$ & $\begin{array}{l}\text { The lesson helps to understand what } \\
\text { information, messages, videos, etc. can } \\
\text { be considered cyber-bullying }\end{array}$ & $\begin{array}{l}\text { Text-based, videos, } \\
\text { interactive quizzes }\end{array}$ \\
\hline APPRAISE & $\begin{array}{l}\text { The lesson provides some useful tools to } \\
\text { critically read and analyse information, } \\
\text { messages, videos, etc. found on the } \\
\text { internet and/or on social media to decide } \\
\text { if they are useful or harmful to health }\end{array}$ & $\begin{array}{l}\text { Text-based, videos, } \\
\text { interactive quizzes }\end{array}$ \\
\hline $\begin{array}{l}\text { Lesson 5 } \\
\text { APPLY }\end{array}$ & $\begin{array}{l}\text { The lesson gives suggestions to decide } \\
\text { if and how to use the information, } \\
\text { messages or videos found/exchanged } \\
\text { online and to avoid some behaviours } \\
\text { becoming cyber-bullying; moreover, } \\
\text { the stories told by children on cyber- } \\
\text { bullying are presented }\end{array}$ & $\begin{array}{l}\text { Text-based, videos, } \\
\text { drawings, interactive } \\
\text { quizzes }\end{array}$ \\
\hline
\end{tabular}

Table 2: Lessons, aims and type of content of the MOOC on health and cyber-bullying

After the use of the MOOC, the children were given an online evaluation questionnaire to assess the quality of the co-creation activities and the resulting MOOC. The online evaluation questionnaire contained questions on the acquired skills and on the quality of the MOOC structure.

\subsection{Analysing and Evaluating the Data}

The storytelling and the answers to the questionnaire were analysed in order to extract information on experiences, difficulties, needs and knowledge among co-creators on the MOOC topic. The extracted information was used to define the structure of the MOOC and the first draft of some contents. The final version of the MOOC was developed by integrating the drawings, stories and voices of the learners, as well as the comments and suggestions that emerged during the meetings.

Moreover, the pre-self-assessment and post-self-assessment questions were analysed in order to evaluate whether and how much students' awareness and knowledge improved.

Finally, the answers to the final evaluation questionnaire were analysed to evaluate satisfaction.

\subsection{Preparing a Report}

The analysed data were discussed to understand: (i) if the MOOC represented a stimulus for enhancing the student's awareness and knowledge of digital health literacy issues and the cyber-bullying phenomenon; and (ii) the students' satisfaction with the 
MOOC in general and with the proposed learning materials. The obtained results are discussed in the following section.

\section{Results}

The case study made evident a positive impact of co-creating the learning content of the MOOC. Children deeply discussed the cyber-bullying problem, the effects on the health, and how to use the internet correctly by preventing unhealthy habits and behaviours.

To evaluate if the MOOC represented a stimulus for amplifying learning experience as well as the children's knowledge and awareness of digital health literacy issues, and particularly of cyber-bullying, the students' answers to pre-assessment and post-assessment questions were analysed (see Table 3).

\begin{tabular}{|c|c|c|c|c|}
\hline Lessons & Questions & & Mean & Variation \\
\hline \multirow{2}{*}{ Lesson 2} & $\begin{array}{l}\text { Pre- } \\
\text { assessment } \\
\text { question }\end{array}$ & $\begin{array}{l}\text { How would you rate your ability to find useful } \\
\text { information about cyber-bullying on the } \\
\text { internet? }\end{array}$ & 0.56 & \multirow[t]{2}{*}{$39.28 \%$} \\
\hline & $\begin{array}{l}\text { Post- } \\
\text { assessment } \\
\text { question }\end{array}$ & $\begin{array}{l}\text { After this lesson, how would you rate your } \\
\text { ability to find useful information about cyber- } \\
\text { bullying on the internet? }\end{array}$ & 0.78 & \\
\hline \multirow{2}{*}{ Lesson 3} & $\begin{array}{l}\text { Pre- } \\
\text { assessment } \\
\text { question }\end{array}$ & $\begin{array}{l}\text { How would you rate your ability to understand } \\
\text { the information found on the internet and use } \\
\text { it to answer your questions about cyber- } \\
\text { bullying? }\end{array}$ & 0.49 & \multirow[t]{2}{*}{$34.69 \%$} \\
\hline & $\begin{array}{l}\text { Post- } \\
\text { assessment } \\
\text { question }\end{array}$ & $\begin{array}{l}\text { After this lesson, how would you rate your } \\
\text { ability to understand the information found on } \\
\text { the internet and use it to answer your questions } \\
\text { about cyber-bullying? }\end{array}$ & 0.66 & \\
\hline \multirow[b]{2}{*}{ Lesson 4} & $\begin{array}{l}\text { Pre- } \\
\text { assessment } \\
\text { question }\end{array}$ & $\begin{array}{l}\text { How would you rate your ability to recognize } \\
\text { if the information found on the internet is } \\
\text { useful or harmful for your health? }\end{array}$ & 0.64 & \multirow[t]{2}{*}{$28.12 \%$} \\
\hline & $\begin{array}{l}\text { Post- } \\
\text { assessment } \\
\text { question }\end{array}$ & $\begin{array}{l}\text { After this lesson, how would you rate your } \\
\text { ability to recognize if the information found on } \\
\text { the internet is useful or harmful for your } \\
\text { health? }\end{array}$ & 0.82 & \\
\hline \multirow[b]{2}{*}{ Lesson 5} & $\begin{array}{l}\text { Pre- } \\
\text { assessment } \\
\text { question }\end{array}$ & $\begin{array}{l}\text { How would you rate your ability to decide } \\
\text { whether and how to apply information, } \\
\text { messages, videos, etc. found or shared online? }\end{array}$ & 0.49 & \multirow[b]{2}{*}{$38.77 \%$} \\
\hline & $\begin{array}{l}\text { Post- } \\
\text { assessment } \\
\text { question }\end{array}$ & $\begin{array}{l}\text { After this lesson, how would you rate your } \\
\text { ability to decide whether and how to apply } \\
\text { information, messages, videos, etc. found or } \\
\text { shared online? }\end{array}$ & 0.68 & \\
\hline
\end{tabular}

Table 3: Students' answers to pre-assessment and post-assessment questions

The answers were rated using a five-point Likert scale [Likert 1932] with the categories 'Very Poor' (corresponding to 0), 'Poor' (corresponding to 0.25), 'Average' (corresponding to 0.5), 'Good' (corresponding to 0.75), and 'Very Good' 
(corresponding to 1). In Table 3, the means of the answers given by children to each pre-assessment and post-assessment question and the percentage variation between preand post-assessment are shown. A positive percentage variation ranging from 28.12 to 39.28 resulted from the analysis. This means that the students' perception of their ability to find, understand, recognize and apply useful information about cyber-bullying and digital health literacy was improved and the MOOC produced an enhancement of the student's awareness and knowledge of digital health literacy issues and the cyberbullying phenomenon.

To evaluate the students' satisfaction with the MOOC in general, and with the learning material produced, children completed a final questionnaire. The questionnaire contained multiple-choice questions (see Table 4) and a section for collecting free comments from children offering suggestions to improve the MOOC. The first five questions were focused on understanding the MOOC content perception, while the last two rated the quality and design.

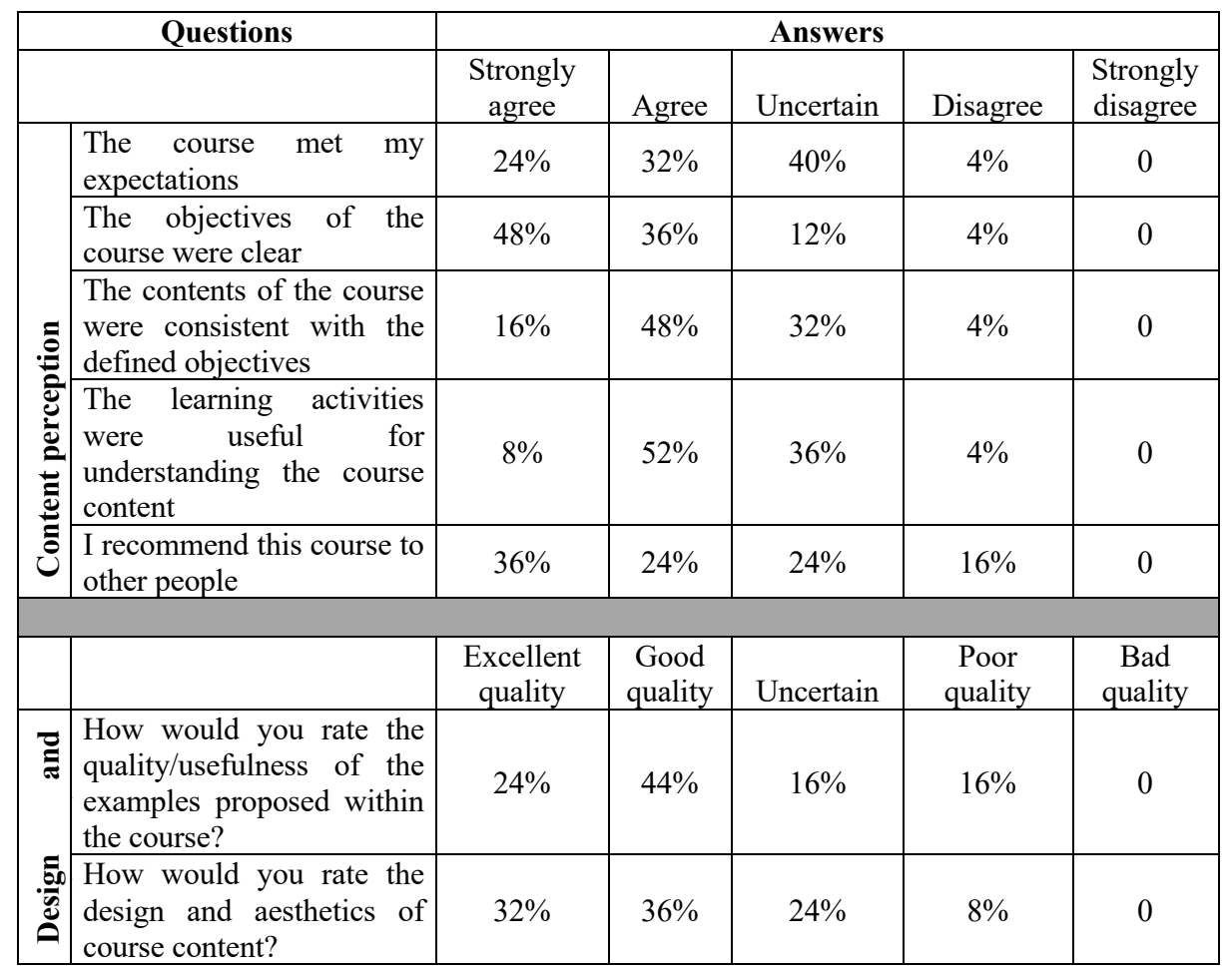

Table 4: Percentage of students' answers to the final questionnaire

To evaluate the content perception, answers were rated using a five-point Likert scale with the categories 'Strongly agree', 'Agree', 'Uncertain', 'Disagree', and 'Strongly disagree'. The 'uncertain' value was considered as the neutral response and was analysed separately by reporting the percentage of participants that gave this answer. Analysis of the results underlines that a representative percentage of students (an average of $28.8 \%$ ) is uncertain in expressing a perception of the MOOC content, as 
shown in Table 4. This is due to some children's difficulties in understanding the questions clearly, as expressed by the students in the comments section of the questionnaire. The majority of the students (around 60\%, considering both 'strongly agree' and 'agree' values) positively evaluated the MOOC content, with a maximum of 84 per cent agreeing about the clarity of the objectives of the course and a minimum of 56 per cent agreeing about the expectations satisfied by the course. An average of only 6.4 per cent of students had a negative perception of the MOOC content ('strongly disagree' and 'disagree' values were considered).

To evaluate the design and quality, answers were rated using a five-point Likert scale with the categories 'Excellent quality', 'Good quality', 'Uncertain', 'Poor quality', and 'Bad quality'. Analogously to the previous evaluation, several students (an average of $20 \%$ ) were uncertain in expressing an opinion; 68 per cent of the students rated the MOOC design and quality positively, while around 10 per cent expressed a negative opinion. Some important adjustments to improve the MOOC were suggested in the free comments section, where students highlighted the need to:

- Put photos and images of cyber-bullying

- Avoid repetition of some sentences

- Improve the audio quality of the videos

Therefore, we can state that satisfaction with the MOOC in general, as well as satisfaction with the learning materials, was positive.

\section{Conclusions}

This study provided a technology-enhanced intervention based on a co-creation strategy that integrated two technological approaches (video storytelling and the MOOC) and two participative methodologies (open space technology and storytelling) to design the MOOC e-learning contents.

The co-created MOOC provided students with critical knowledge concerning the phenomenon of cyber-bullying. The first part of the MOOC explored the correct use of ICT technologies, giving some suggestions on how to correctly search, understand and apply information on the Web. The second part of the MOOC covered the prevention and intervention strategies that students have to carry out to counter and reduce cyberbullying actions. Students must be very careful both in posting personal information online (such as full name, address, telephone number, school name, parents' names or credit card number) and sharing their own internet passwords with anyone, and never meet face-to-face with someone only met online. Moreover, telling friends to stop cyber-bullying, blocking communication with cyber-bullies, and reporting cyberbullying to a trusted adult represent important actions to carry out to hinder the cyberbullying phenomenon.

The results obtained from the implemented case study confirm our hypothesis that the use of a co-creation approach to design the MOOC allows amplification of the learning experience as well as the children's knowledge and awareness of digital health literacy issues, and particularly of cyber-bullying. Co-creating provided multiple means of representation through student-centred collaboration. This means that students could say how they would like to see the MOOC represented and assessed. The MOOC learning experience was tailored to individual student needs. 
The MOOC is of high interest for Italian students, but also for adult people from different backgrounds (e.g. sociologists, psychologists, public health educational scientists and pediatricians) who wish to expand their knowledge and understanding of cyber-bullying among children and youth. Given the twofold focus on both research and intervention, the MOOC is also particularly suggested to people actively engaged in the education and well-being of children and adolescents (such as teachers, school counsellors, school nurses, policymakers, etc.). In this direction, we will apply the cocreation process in the design and development of MOOCs focused on further social issues involving children and adolescents, such as social exclusion. The aim is twofold: to test the proposed approach in other contexts, collecting more data to validate its efficacy and effectiveness, and to improve children's and adolescents' awareness and knowledge of the main current social issues.

\section{Acknowledgements}

This study was realized within the IC-Health project, which is funded by the European Union's Horizon 2020 Research and Innovation Programme (Grant no. 727474). We thank the students in the fourth and fifth grades (school year 2017/2018) and teachers Giuseppina degli Uberti and Laura Buongiorno Nardelli at the Pestalozzi school of Rome, who were very supportive and allowed us to conduct the study.

\section{References}

[Abercrombie, 1984] Abercrombie, N., Hill, S., Turner, B.: "Dictionary of Sociology"; Penguin, London, England (1984)

[Agrusti, 2017] Agrusti, F., Poce, A., Re, M.: "MOOC Design and Heritage Education. Developing Soft and Work-based Skills in Higher Education Students"; Journal of e-Learning and Knowledge Society, 13 (2017) 83-96

[Allin, 2014] Allin, L.: "Collaboration between Staff and Students in the Scholarship of Teaching and Learning: The Potential and the Problems"; Teaching and Learning Inquiry, 2, 1 (2014), 95102. doi:10.2979/teachlearninqu.2.1.95

[Ashktorab, 2016] Ashktorab, Z., Vitak, J.: "Designing Cyberbullying Mitigation and Prevention Solutions through Participatory Design with Teenagers"; Proceedings of the $2016 \mathrm{CHI}$ Conference on Human Factors in Computing Systems, ACM, Santa Clara, California (2016), 3895-3905

[Bartoletti, 2016] Bartoletti, R.: "Learning through Design: MOOC Development as a Method for Exploring Teaching Methods"; Current Issues in Emerging eLearning, 3, 1 (2016) https://scholarworks.umb.edu/ciee/vol3/iss1/2

[Bovill, 2014] Bovill, C.: "An Investigation of Co-Created Curricula within Higher Education in the UK, Ireland and the USA"; Innovations in Education and Teaching International, 51, 1 (2014), 15-25. doi:10.1080/14703297.2013.770264

[Bowler, 2014] Bowler, L., Mattern, E., Knobel, C.: "Developing Design Interventions for Cyberbullying: A Narrative-based Participatory Approach”; iConference 2014 Proceedings (2014)

[Caschera, 2019] Caschera, M. C., D’Ulizia, A., Ferri, F., Grifoni, P.: "MONDE: A Method for Predicting Social Network Dynamics and Evolution"; Evolving Systems, 10, 3 (2019) 363-379 
[Caschera, 2012] Caschera, M. C., D’Andrea, A., Ferri, F., and Grifoni, P.: “Knowledge Access and Interaction Evolution in Virtual Learning Communities". Virtual Learning Environments: Concepts, Methodologies, Tools and Applications, IGI Global Berlin, Heidelberg, (2012), 10191038

[Caschera, 2011] Caschera, M. C., D’Andrea, A., D’Ulizia, A., Ferri, F., Grifoni, P., Guzzo, T.: "Toward new Communication Paradigms to Enhance Cognitive and Learning Processes"; Proceedings of the OTM Confederated International Conferences On the Move to Meaningful Internet Systems, Springer, Berlin, Heidelberg (2011), 562-570

[Caschera, 2010] Caschera, M. C., D’Ulizia, A., Ferri, F., Grifoni, P.: “An Advanced Multimodal Platform for Educational Social Networks"; Proceedings of the OTM Confederated International Conferences On the Move to Meaningful Internet Systems, Springer, Berlin, Heidelberg (2010), 339-348

[Cook-Sather, 2014] Cook-Sather, A., Bovill, C., Felten, P.: "Engaging Students as Partners in Learning and Teaching: A Guide for Faculty"; Jossey-Bass. San Francisco, CA (2014)

[Crabtree, 1999] Crabtree, B. F., Miller, W. L.: "Using Codes and Code Manuals in Doing Qualitative Research" (2nd edition); Sage, Thousand Oaks, CA (1999)

[D’Andrea, 2015] D'Andrea, A., Ferri, F., Grifoni, P., Guzzo, T.: “Co-Creativity Process by Social Media within the Product Development Process"; Proceedings of the On the Move to Meaningful Internet Systems 2015: OTM 2015 Workshops Proceedings; Lecture Notes in Computer Science, Rhodes, Greece (26-30 October 2015), Springer-Verlag Publishing, Berlin, Heidelberg, (2015), 559-569

[D'Andrea, 2009] D'Andrea, A., Ferri, F.: “Mobile Devices to Support Advanced Forms of eLearning": Multimodal Human Computer Interaction and Pervasive Services, IGI Global Hershey, PA, (2009), 389-407

[D'Andrea, 2010] D’Andrea, A., Ferri, F., Grifoni, P.: "Social Impacts of Mobile Virtual Communities on Healthcare"; Health Information Systems: Concepts, Methodologies, Tools, and Applications, IGI Global Berlin, Heidelberg, (2010), 1373-1387

[Devers, 1999] Devers, K. J.: "How Will you Know Good Qualitative Research when We See it? Beginning the Dialogue in Health Services Research"; Health Services Research, 34, 5 (1999) $1153-1188$

[Díaz-Méndez, 2012] Díaz-Méndez, M., Gummesson, E.: "Value Co-Creation and University Teaching Quality: Consequences for the European Higher Education Area (EHEA)"; Journal of Service Management, 23, 4 (2012), 571-592. doi:10.1108/09564231211260422

[Dinakar, 2012] Dinakar, K., Jones, B., Havasi, C., Lieberman, H., Picard, R.: “Common Sense Reasoning for Detection, Prevention, and Mitigation of Cyberbullying"; ACM Transactions on Interactive Intelligent Systems (TiiS), 2, 3 (2012), 18

[Eisenhardt, 1989] Eisenhardt, K. M.: "Building Theories from Case Study Research"; Academy of Management Review, 14, 4 (1989), 532-550. doi:10.5465/amr.1989.4308385

[Feagin, 1991] Feagin, J., Orum, A., Sjoberg, G.: “A Case for Case Study”; University of North Carolina Press, Chapel Hill, NC (1991)

[Ferri, 2018] Ferri, F., D'Andrea, A., Grifoni, P., Guzzo, T.: "Distant Learning: Open Challenges and Evolution"; International Journal of Learning, Teaching and Educational Research, 17, 8 (2018) 71-88 
[Ferri, 2014] Ferri, F., Grifoni, P., Caschera, M. C., D’Andrea, A., D’Ulizia, A., Guzzo, T.: “An Ecosystemic Environment for Knowledge and Services Sharing on Creative Enterprises"; Proceeding of the International Conference on Management of Computational and Collective Intelligence in Digital EcoSystems (MEDES '14), 15-17 September 2014, ACM, Qassim in Buraydah, Saudi Arabia (2014), 27-33

[Ferri, 2013] Ferri, F., Grifoni, P., Caschera M. C., D’Ulizia A., Praticò, C.: "KRC: Knowing Crowdsourcing Platform Supporting Creativity and Innovation"; Advances in Information Sciences and Service Sciences, 5, 16 (2013), 1-15

[Frow, 2011] Frow, P., Payne, A., Storbacka, K.: "Co-Creation: A Typology and Conceptual Framework"; Ogilvie, M., Ryan, M. (Eds), Proceedings of the 2011 Australia and New Zealand Marketing Conference, Perth, Australian and New Zealand Marketing Academy (2011), 1-6. ISBN 9780646563305

[Garaigordobil, 2018] Garaigordobil, M., Martínez-Valderrey, V.: "Technological Resources to Prevent Cyberbullying During Adolescence: The Cyberprogram 2.0 Program and the Cooperative Cybereduca 2.0 Videogame"; Frontiers in Psychology, 9 (2018) 1-12

[Gasevic, 2014] Gasevic, D., Kovanovic, V., Joksimovic, S. \& Siemens, G. 2014. "Where is research on Massive Open Online Courses headed? A data analysis of the MOOC Research Initiative". International Review of Research in Open and Distance Learning, 15(5), 134-176. Retrieved from http://www.irrodl.org/index.php/irrodl/article/view/1954/3099?

[Guàrdia, 2013] Guàrdia, L., Maina, M., Sangrà, A.: "MOOC Design Principles: A Pedagogical Approach from the Learner's Perspective"; eLearning Papers, 33 (2013) 1-6

[Guzzo, 2014] Guzzo, T., D’Andrea, A., Ferri, F., Grifoni, P.: "Social Media: The Evolution of e-Health Services"; Social Networks: Analysis and Case Studies, Springer, Vienna (2014), 233248

[Huang, 2010] Huang, C.: "Application of Engagement Theory in the Literary Education"; Journal of Language Teaching and Research, 1, 4 (2010), 460-463. doi:10.4304/jltr.1.4.460-463

[Kearsley, 1998] Kearsley, G., Shneiderman, B.: "Engagement Theory: A Framework for Technology-Based Teaching and Learning"; Educational Technology, 38, 5 (1998), 20-23. https://www.jstor.org/stable/44428478

[Kowalski, 2012] Kowalski, R. M., Limber, S. P., Limber, S., Agatston, P. W.: “Cyberbullying: Bullying in the Digital Age"; Wiley-Blackwell, Malden, MA (2012)

[Küter-Luks, 2011] Küter-Luks, T., Heuvelman, A., Peters, O.: "Making Dutch Pupils Media Conscious: Preadolescents' Self-Assessment of Possible Media Risks and the Need for Media Education"; Learning, Media and Technology, 36, 3 (2011), 295-313

[Le Play, 1879] Le Play, F.:"Les ouvriers européens (2e édition), tome premier, la méthode d'observation appliqué de 1829 à 1879, à l'étude des familles ouvrières“" (1879), 110, 13 -16.

[Likert, 1932] Likert, R.: "A Technique for the Measurement of Attitudes"; Archives of Psychology, 140 (1932), 1-55.

[Liyanagunawardena, 2013] Liyanagunawardena, T. R., Adams, A. A., Williams, S. A.: "MOOCs: A Systematic Study of the Published Literature 2008-2012"; The International Review of Research in Open and Distributed Learning, 14, 3 (2013), 202-227. doi:10.19173/irrodl.v14i3.1455

[Miles, 1984] Miles, M., Huberman, M.: "Qualitative Data Analysis: A Source Book for New Methods"; Sage Publications, Beverly Hills, CA (1984) 
[Nocentini, 2015] Nocentini, A., Zambuto, V., Menesini, E.: “Anti-Bullying Programs and Information and Communication Technologies (ICTs): A Systematic Review"; Aggression and Violent Behavior, 23 (2015), 52-60. doi:10.1016/j.avb.2015.05.012

[Norman, 2006] Norman, C. D., Skinner, H. A.: "eHealth Literacy: Essential Skills for Consumer Health in a Networked World"; Journal of Medical Internet Research, 8, 2 (2006) 1-10

[Nygaard, 2013] Nygaard, C., Brand, S., Bartholomew, P. Millard, L.: "Student Engagement: Identity, Motivation and Community"; Libri Publishing, Farringdon, United Kingdom (2013)

[Osuna-Acedo, 2017a] Osuna-Acedo, S., Frau-Meigs, D., Camarero-Cano, L., Bossu, A., Pedrosa, R., Jansen, D.: "Intercreativity and Interculturality in the Virtual Learning Environments of the ECO MOOC Project". Jemni, M., Kinshuk, Khribi, M. (Eds), Open Education: From OERs to MOOCs: Lecture Notes in Educational Technology; Springer, Berlin, Heidelberg (2017)

[Osuna-Acedo, 2017b] Osuna-Acedo, S., Gil Quintana, J., Cantillo Valero, C.: “Open, Mobile and Collaborative Educational Experience. Case Study: The European ECO Project"; Journal of Universal Computer Science, 23, 12 (2017), 1215-1237

[Puzziferro, 2008] Puzziferro, M., Shelton, K.:. “A Model for Developing High Quality Online Courses: Integrating a Systems Approach with Learning Theory"; Journal of Asynchronous Learning Networks, 12, 3-4 (2008), 119-136. http://files.eric.ed.gov/fulltext/EJ837519.pdf

[Ryan, 2000] Ryan, G. H., Bernard, H. R.: "Data Management and Analysis Method". Denzen, N. K., Lincoln, Y. S. (Eds), Handbook of Qualitative Research (2nd edition), Sage, Thousand Oaks, CA (2000)

[Stake, 1995] Stake, R.: "The Art of Case Research", Sage Publications, Newbury Park, CA (1995)

[Topcu-Uzer, 2018] Topcu-Uzer, C., Tanrıkulu, İ.: “Technological Solutions for Cyberbullying"; Reducing Cyberbullying in Schools, Academic Press, Cambridge, MA, (2018), 33-47

[Vissak, 2010] Vissak, T.: "Recommendations for Using the Case Study Method in International Business Research"; The Qualitative Report, 15, 2 (2010): 370-388 http://nsuworks.nova.edu/tqr/vol15/iss2/8

[White, 2016] White, S., White, S.: "Learning Designers in the 'Third Space': The SocioTechnical Construction of MOOCs and their Relationship to Educator and Learning Designer Roles in HE"; Journal of Interactive Media in Education, 1 (2016). doi:10.5334/jime.429

[Yin, 1994] Yin, R. K.: "Case Study Research Design and Methods”, Sage Publishing, London, England (1994) 